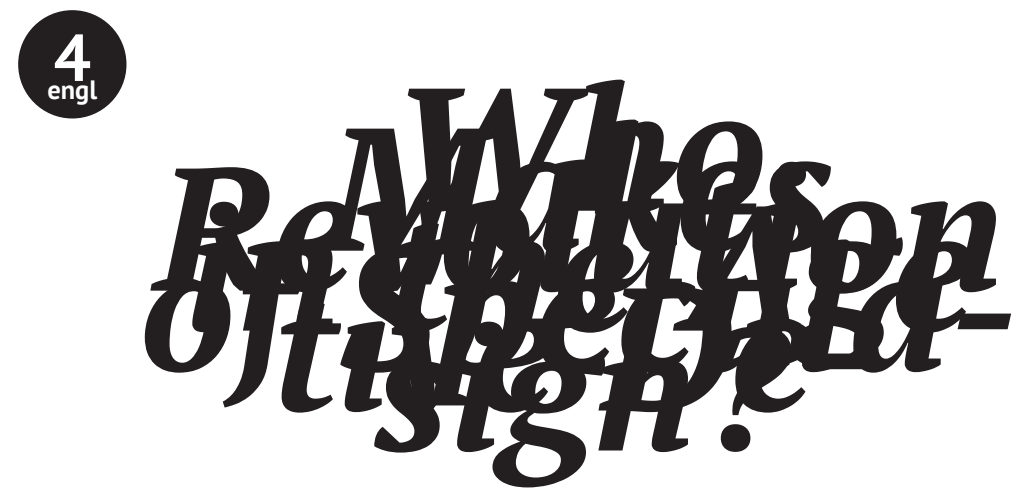

\title{
Keti Chukhrov
}

National Research University Higher School of Economics, Moscow Marie Curie Fellowship, University of Wolverhampton, U.K. E-mail:keti.chukhrov@gmail.com

\section{Who Makes Revolution in the Age of Speculative Design?}

\begin{abstract}
Contemporary theories of social emancipation contend that it is time to dispense with the concept of revolution and leave it merely as the legacy of political struggles belonging to the age of industrial economy. Today's globalization, semio-capital, speculative design, ${ }^{2}$ crypto-economy, and artificial intelligence would engage epistemologically different emancipatory lexicons and techniques of resistance. All new futurisms posit
\end{abstract}

1 Results incorporated in this publication have received funding from the European Union's Horizon 2020 research and innovation program under the Marie Sklodowska-Curie grant agreement № 752417.

2 Speculative design is a term coined by the designer Anthony Dunne in the 1990s to define a form of social design that must question the cultural, social, and ethical implications of future technologies and "define the most desirable futures, avoiding the less desirable." The term is applied in studies of algorithmic architecture, artificial intelligence, and post-human studies by Benjamin Bratton, Mark Wigley, Phil Balagtas, and others. 
technological solutions for hitherto political stakes. What remains unheeded in them is the existential need for cognitive equality and social continuity with the masses in constructing the collective subject of emancipation. Recent election results in the

U.S., U.K., Eastern Europe, and Russia diagnose an immense cognitive rupture between the producers of emancipatory lexicons and disadvantaged workers. Such a split between mind and body was already made apparent in Hegel's dialectics of lord

and bondsman. In order to surpass this split, it is of utmost importance to reconsider the conditions in which the premature construction of the proletariat took place in the context of the October revolution. The proletariat was posited in this case not only as revolutionary subject, but as the principal subject of Enlightenment as well.

Keywords

Acceleration, Ataraxia, Bondsman, Dictatorship of the Proletariat, Hegel, Lord, Semio-capital, Subject of Enlightenment

\section{Introduction}

In contemporary techno-oriented emancipatory programs, the idea of repoliticizing the social sphere - as well as the term revolution is dismissed in favor of reprogramming the capitalist machine. Accelerationist, cybernetic, xenofeminist, and ANT (Actor Network Theory) futurologies alike identify techno-scientific development as a productive force capable of superceding political deadlocks. They privilege a redesign of the software of cognitive practices and technological inventions over politics - an idea that sounds rather more like a solidarity appeal to silicon valley workers than broad solidarity with the working masses or disenfranchised social groups. While this defiance of revolution and of the political subject in techno-scientific theories of emancipation is justified on the grounds of the inevitable technological reconstitution of social agencies, such theories ignore the fact that it is to a considerable extent political will and existential and ontological need that is able to establish continuity with the unprivileged masses and delegate them the tools for social, economic, and cognitive subjectivation.

Interestingly, one of the primary demands of the October revolution was an overall - even coercive - equalization in knowledge and educa- 


\section{Keti Chukhrov}

tion. For Marx and Lenin, the proletariat is not merely the working class, struggling for political emancipation. It is the class which, despite its deprivation, is able to prematurely acquire self-consciousness, i.e. to posit itself as a supreme subject of knowledge, and embody the most developed stage of consciousness - even ahead of any nominal grasp of the cognitive outcomes, technologies, and productive forces that would allow it to reach such a developed stage. What facilitates this power for the proletariat "ahead of time" is its dictatorship - the result of a revolutionary seizure of power. In the midst and aftermath of the October revolution, the goal of diminishing the split between mind and body had served as the focal point of struggle. The question is whether the contemporary enlightened cognitive producer is able to solve the problem of rupture by using lexicons of emancipation that divide society into a socially progressive "intelligentsia" and an obscurantist brain-washed masses a rupture which continues to determine the success of conservative political forces today.

\section{Knowledge as Capital}

Knowledge, practices of mind, and proper legibility in technologies have today become the principal stumbling block that hampers the continuity and efficacy of emancipation; they manifest the extent to which emancipatory projections are dependent on certain lexicons and their cognitive accessibility and comprehensibility. Those who speak these languages are not the most oppressed; those who are most oppressed do not speak these languages. Under the conditions of semio-capital, knowledge and the general intellect have gradually become the chief form of property, wealth, and means of production - so that it is rather inequality in knowledge, which causes insult and resentment amongst the underprivileged layers of society. Those who elect conservative leaders are less insulted by the luxury, smuggled property, corruption, and authority of those leaders, than they are by disregard on the part of the progressive intelligentsia, with their opaque lexicons of sophisticated culture, enlightenment, and education. ${ }^{3}$

The conservative turn that we witness today across multiple geopolitical regions is the proof that even the most emancipatory undertakings in art and culture have failed to make knowledge and intelligence appli-

3 Such a claim is substantiated by support among insecure and disenfranchised social groups for Brexit, the Trump presidency, the conservative "Georgian Dream" party in Georgia, and for Putin and the "United Russia” party, despite evidences of the latter's becoming de facto a ruling oligarchy. 
cable for the disenfranchised masses. What makes the solidarity of cognitive workers as the main emancipatory agency questionable is that the expansion of common good is identified in this case with broadened areas of applied knowledge by means of either new landscapes of design and logistics, or new speculative and artistically grounded intelligences. Yet such agencies remain heedless of the political and economic organs that would broaden the ethics of the common good. This automatically ascribes cognitive advancement to a specific social stratum - the technically and cognitively enlightened "intelligentsia" - which then, because of its intellectual legibility, remains the sole political subject of emancipation.

Thus at stake is the unsurpassable rupture between a cognizing and accelerating advancement and the needs of the body and its conditions of survival - a rupture that segregates the social classes and various geopolitical regions. Until recently, the agenda of many cultural institutions was to pursue programs in social education or participatory initiatives with the aim of lubricating social antagonisms and cognitive and cultural inequalities. One of the achievements of cognitive capitalism, as it was thought, was accelerative growth and access of the masses to the general intellect. In accelerationism's emancipatory programs, the idea of a revolutionary repoliticization of the social sphere was dismissed in favor of a reprogramming of the capitalist machine. Technological advancement - i.e. soft sociality - was held to be capable of tackling political deadlocks better than body (folk) politics (Srnicek and Williams 2014: 347-363). According to this standpoint, the efficacy of social emancipation lies in recreating/developing the software of cognitive practices and technological inventions, rather than in enacting political "choreography” (Berardi 2017). This belief however reveals several aberrations; one of them being that, in the aforementioned theories, the subject of emancipation - as well as the subject of precarity, - is chiefly an intellectual worker, whose task it is to retrieve the means of production from semio-capital and to rechannel them against neoliberal domination. Yet thus far, neither algorithmization and the cybernetic rebranding of social services and labor, nor the proliferation of the languages of political critique in the culture industry - even when presented as democratic and accessible - have duly been recognized by the laboring masses as the source of their enlightenment and welfare. Those most utterly deprived in this case become a merely formal component of emancipatory argumentation. In fact, techno-futurist imaginaries have not managed to increase the domains of equality, despite access to free common digital consumption. This is because the diverse resources of enlightenment and of cognitive growth are not only a matter of access and consumption, but also of a certain social jargon, which, more often than not, has remained untranslatable and hence blank for the majority of the population. This ten- 


\section{Keti Chukhrov}

dency leaves unheeded an insightful reminder from Maurizzio Lazzarato about the need to maintain an epistemological difference between technology/engineering on the one hand, and sociality, on the other (Lazzarato 2016). For Lazzarato, technology forms part of the war machine of capital, thus it should not be identified with sociality; technological progress does not necessarily imply social emancipation.

The aforementioned split between cognitive design and bodily sociability diagnoses a paradoxical situation: the neoliberal technocratic elites and enlightened progressive cultural workers "happen" to be more socially homogenous than the underprivileged masses and progressive intellectual workers. Hence it is no surprise that neoliberal "democratic" governments, NGOs, and cultural institutions in almost all post-socialist countries have been overtaken by nationalist, anti-globalist, and "antineoliberal" conservative oligarchies, which are often supported not only by former communist party remainders, but at times even by grassroots left communities. ${ }^{4}$ Openly expressing contempt for the global cultural or academic fields, these grassroots anti-globalists often regard conservative leaders, or even the heads of national oligarchies - Erdogan, Orban, Putin, Trump, Ivanishvili - as a Syriza-type resistance against global financial and cultural bureaucratic elites. Therefore, only a more sophisticated view of the conservative turn would allow us to see that traditionalism and the restitution of religion might not be a case of ardent faith or the protection of essentialist values. The real intention behind cultural traditionalism and regionalization is not the fight against modernity. On the contrary, it is often a revolt and resentment rooted in not being apt for enlightened and emancipated techno-contemporaneity and its lexicons.

What is striking when watching the documentary materials of the Comintern congress of 1921 is that most of the brilliant communist proponents of proletarian revolution - Lenin, Radek, Trotsky - belonged to the middle class, the intelligentsia - to the enlightened bourgeoisie. Nonetheless, it was they who initiated the empowerment of the proletariat as the universal subject of history, to then go on to institute its afterrevolutionary dictatorship. Such a disposition - that middle-class leftist cultural workers establish social continuity with the most disadvantaged working layers of society, and moreover, establish this subjugated subjectivity as the avant-garde of emancipation and even of cognitive and tech-

4 For example, in 2012 major leftist parties and organizations in Georgia supported the party of oligarchic capital "Georgian Dream" against the previous pro-western (neo)liberal democratic government. In Russia, during the confrontation with the Ukraine, a well-known leftist organization, "The Institute of the Problems of Globalization," founded by sociologist and activist Boris Kagarlitsky, (although without any direct support from the ruling party "United Russia”), gave explicit preference to Putin's government as against the pro-western neoliberal opposition. 
nical production - would be unimaginable today. Should we ascribe this to a particular historical moment, to the proliferation of grassroots emancipatory movements then and to their lack now? What is the proletariat as a political subject? Is it merely a politically organized class of laboring masses? Or does this concept bear on something more than merely social emancipation?

\section{II The Ataraxia of Cognitive Emancipators}

Hegel, in his short passage on the dialectics of lordship and bondage, touches upon a very subtle point of how and when the lord-bondsman dependency is sublated. He argues that the overcoming of this bond happens in Stoicism. As we recall from this passage (1977: 104-138), the lord is free from actual existence, does not have to do with it, and his consciousness is therefore independent. The bondsman, on the contrary, is submerged in the production and formation of things - in existence and hence, his consciousness is reified. The lord's problem is nonetheless that while his consciousness is being for itself, is sovereign and universal, he still needs to consume, and hence retains a longing for the object world. Thus he needs "another consciousness", that would deal with actual things in order to help him to mediate reality; the lord cannot access reality without the bondsman's labor. His need of consumption and of the bondsman's labor reveals that his independence of consciousness is not a true independence. Moreover, what is extremely important to note is that, as Hegel states, in confining his contact with the world to mere consumption of the thing, the master can only annihilate what he longs for and consumes. Only the servant's formative labor and activity saves the object from total annihilation. Very important here is that Hegel disputes his own initial claim that consciousness, for its formation and generality, should be detached from reality and abstracted. Hegel first posits abstract universality as the main trait of the lord's consciousness, only to later overturn his own premise and show that it is impossible to acquire universal consciousness in complete detachment from the material world; labor is essential to the acquisition of consciousness. Thus neither the servile labor of the bondsman, nor the lord's contact with the world through the bondsman's labor, are adequate means for acquiring consciousness.

This is the reason why Hegel brings forth the Stoicist state of mind. Here, consciousness truly exceeds the lord-bondsman confrontation. The Stoic manages to sublate the split between the bondsman's submergence in actual existence and the lord's abstracted "I." This happens because the Stoic subject prefers not to consume at the expense of the bondsman, and thus rejects the position of lord. He dispenses with 
the bondsman, since truly free consciousness is one that is free from dependence on someone else's labor, and only in the case of such liberation is the subject capable of thought, capable of uplifting labor and formative activity (Bildung) to thought. Yet, as Hegel emphasizes, despite this act of liberating consciousness, Stoicism does not answer the question of where the true and the virtuous lies, but instead generates a contentless thinking - seeking thought in mere reasoning (Ibid: 122).

Thought and thinking do not grasp the living world in this case. This is because, despite setting the bondsman free, the Stoic does not preserve a tie with the objective world, and thus exacerbates the split between body and mind to an even greater extent than the feudal lord; the lord had at least preserved a minimal tie with the world at the expense of bondsman's labor. As long as the free and enlightened Stoic does not need subjugated labor, all former bondsmen are allowed to become free independent citizens and to exchange their labor with a former lord on equal terms. Meanwhile, the Stoic ex-lord guarantees the ceremony of democracy and equality for the former bondsman, while being tacitly aware of his own advantage and superiority. In fact, with this figure of the Stoic, Hegel gives the model of the enlightened bourgeois subject who benevolently declines his lordship, yet is nevertheless unable to provide recognition for those who remain inferior. ${ }^{5}$

In this situation, inequality and inferiority are disguised by the procedures of civility and its legislation. It seems at first sight that this new fusion of civic equality and a tacit subordination of the inferior packaged as civility derives from the stoic's hegemony in cognition and knowledge (Bildung). Yet much more important in preserving his privilege is the stoic's ataraxia (indifferent equanimity) - the condition that guides the stoic in his non-involvement with the world. It is precisely ataraxia that keeps the Stoic's knowledge (Bildung) appropriated for his own self, and prevents him from granting recognition to all those who do not fit into the cognitive exigencies of Bildung. Due to this appropriated, exclusive knowledge (ataraxia) the Stoic maintains his tacit and concealed lordship. It is here that the mutation from the former feudal lord to the enlightened bourgeois subject takes place.

Thus even when the former bondsman is legally acknowledged as free citizen and works as wage laborer, s/he does not become for "the Stoic" the subject of knowledge, judgement, and recognition. As long as juridically all are equals, it suffices for "the Stoic" to exercise his or her civil duty in employing a rhetoric of solidarity for the inferior, instead of producing any general ground for converging the two - knowledge and

See also Jason Read's Politics of Transindividuality for an analysis of how labor transforms into Bildung and self-consciousness in this passage of the Phenomenology of Spirit (2016: 38-57). 
the objective world, mind and body, superiority and inferiority. Consequently, those who represent cognitive inferiority are de facto a surplus for the Stoic mind, despite any juridical equality or a formal rhetoric of the commons.

In fact, as Hegel argues, the Stoic's ataraxia subsists in the fact that even in its detachment from the objective world, the Stoic's thought does not exercise this withdrawal to the full. As Hegel puts it, "[t]his thinking consciousness as determined in the form of abstract freedom is thus only the incomplete negation of otherness. Withdrawn from existence only into itself, it has not there achieved its consummation as absolute negation of that [existence]" (Ibid: 122). Ataraxia implies this equanimity and balance; neither a Marxian zeal of involvement with the worldly, nor a radical Nietzschean detachment from the world.

Further on, in Chapter 6 of The Phenomenology of Spirit, Hegel confirms his point by repeating that Stoicism is the consciousness that abuses the legal status as abstract form. It formally proclaims the rights and independence of every individual, yet it "does not attach its being to anything that exists" (Ibid: 291). Consciousness of formal legal right is devoid of involvement in reality. Hegel calls the solitary self of the lawabiding Stoic "impotent," despite the fact that it manages to obtain "a complete supremacy" for such formalized consciousness (Ibid: 292, 293)

Does not this position recall the role of the contemporary progressive intellectual, an enlightened subject standing for emancipation, who, having no social continuity with the underprivileged, speaks the languages of progressive citizenship, yet has ever been remote from any harsh social and cognitive deprivation, and has never been in need of questioning his or her own social and cognitive privileges and advantages, not to say anything of abandoning them?

Now let us look closer at the consequences of this procedure: the inferior worker is alleged to be an equal citizen, an average waged laborer. Yet while "the Stoic" remains in his realm of privileged cognitive production, the inferior former bondsman - who is aware of the falsity of civic rhetoric and who feels him or herself to be a surplus in relation to the subject of knowledge - simply self-employs with the neo-lord, entering an illusionary heterotopia, a neo-feudal incestual "family," the "sincere" body of a community.

We witness, in this case, the emergence of unofficial heterotopic sites - religious communities, esoteric and occult subcultures, shadow economies, and mafia brotherhoods - which conceal segregation; they contrive a fictitious equality between otherwise unequal social agents. A 
strange quasi-feudal potlatch takes place then between superiors and inferiors. The superior tempts the inferior with informal conduct and care, whereas the inferior provides for the superior acts of "unofficial" devotion that surpass any social roles and institutions. This explains why the present rupture in populist politics is not between the wealthiest and the most impoverished, but between the enlightened transnational middle class, i.e. the bearers of global knowledge, and the obscurantist local masses. Moreover, authoritarian governments and re-feudalized oligarchic clans succeed in setting the rage of the masses against the enlightened "Stoics," presenting the latter as global rulers/"experts" contemptuous of the rabble. This quasi-feudal heterotopia of "commons" can easily become a potential site of coercion between the superior and the inferior; yet it at least spares "the bondsman" from feeling his or her own redundancy, which is made so painfully obvious in the civic emancipatory rhetoric of "the Stoicist."

It is deplorable that cognitive capitalism, technical excellences, and software sociality (Berardi 2017) have converged with contemporary "emancipatory" cultural production without extending emancipation towards zones of deprivation. The consequence of this is not only the progressive intelligentsia's involuntary and tacit contempt of cognitively illegible layers of society, nor the resentment of the traditional and nationalist "folk" towards the "intelligentsia," but the split within capital itself, which has created the illusion of two models of capitalism functioning simultaneously - global, financial capital, and a resource-oriented, territorial, autocratic, and oligarchic one. The latter pretends to be post-capitalist in its formal rhetoric, yet remains capitalist in content; both modes of capitalism are palpably two sides of the same coin. Post-Fordist capitalism has never surpassed primitive accumulation; technocratic acceleration and obscurantist fundamentalism remain intertwined. Moreover, to repeat again, national, autocratic capital persists in nationalist policies not so much because of any essentialist patriotism, but exactly because its agents are excluded from the pool of global financial players. For the outsiders of the global economy, nationalist policies and the essentialization of culture become the remedy with which to protect their capitals, and "an umbrella" with which to conceal the monetization of the social sphere.

The rupture between these two modes of capital engenders a condition of global civil wars (Alliez and Lazzarato 2017). Resource capital, shadow production, and oligarchic finance are unleashing a war against global semio-capital, which has itself reached the edge of humanitarian catastrophe in dividing humanity into anthropological types according to their cognitive and civilizational legibility. 


\section{Proletariat - the Premature Subject of Enlightenment}

Who then could be the universal subject of knowledge and consciousness, able to connect the abstraction of thought with the concrete formation of things, the body and the mind? Historically, the proletariat was considered to be the subject that would acquire a consciousness that would be both general in its speculative scale, and concrete in the application of this generality within objective existence. It was only the proletariat that was endowed by Marx with the capacity to turn labor into generalized knowledge and Bildung. In History and Class Consciousness (1971 [1923]), Lukács claimed that the proletariat's class consciousness was in fact the production of what consciousness must be per se. A similar argument was made by Andrey Platonov, who wrote that "the soul of the bourgeoisie is desire and sexuality," whereas "the soul of the proletariat is consciousness" (1988 [1925]: 532).

Class consciousness is not a psychological state but a historical condition. Bourgeois consciousness is not yet any consciousness at all, since its goals are confined merely to self-interest. Therefore, the bourgeoisie as a class resides outside of the historical development of consciousness. The bourgeoisie sees the contradictions confronting it as "the outer limits of its consciousness" (Lukács 1971 [1923]: 72). ${ }^{6}$ Meanwhile, the consciousness of the proletariat encompasses the dialectical contradiction between its immediate economic interests and its long-term political objectives. This means that it is only in the consciousness of the proletariat that not only immediate interests, but the objective "good" of the whole society can be located (Ibid.: 71).

The proletariat, as we remember, is the class that transcends its servile social condition by acquiring an almost fantastic stance of consciousness, in which it surpasses its own deprivation to conceptually and ontoethically posit the universal withering away of all deprivation. Meanwhile, in this acquisition of the universality of consciousness, a proletarian is not only the avant-garde of political emancipation or a historical subject, but a supreme philosophical subject. It is worth mentioning that in this light, Marx's 11th thesis on Feuerbach - which is traditionally interpreted as a dismissal of speculative philosophy in favor of social practice might acquire a converse meaning. The thesis could be understood, on the contrary, as a totalization of philosophy, as positing in the role of the enlightened, philosophical subjects precisely the lowest and most

6 "It is true that the bourgeoisie acts as a class in the objective evolution of society. But it understands the process (which it is itself instigating) as something external which is subject to objective laws which it can only experience passively" (Lukács 1971 [1923]: 63). 


\section{Keti Chukhrov}

disadvantaged social strata - thus making philosophy the mundane habit of each and all, rather than proclaiming its expulsion from social and political practice. It is in this sense that the proletariat is not only the principal subject of deprivation, but also the principal subject of enlightenment, mind, thought, and knowledge, embodying the most developed stage of consciousness even before it acquires skills in education and technologies, i.e. before productive forces could have guaranteed such advancement. The Comintern revolutionaries - notwithstanding their origins in the intelligentsia, bourgeoisie, or even the gentry - were not distancing themselves from defending the interests of the oppressed, or worse still, pretending to be oppressed themselves (an aberration that is often the case with today's cognitive precariat); they also posited the oppressed as the supreme subject of knowledge and thought in creating the social construct of the proletariat. In this way, they practiced a radical anti-ataraxia themselves. ${ }^{7}$

The Comintern revolutionaries who identified with the proletariat might be regarded as "anti-Stoics" who voluntarily dismissed their cognitive hegemony in favor of another, more universal, consciousness outlined in the subjectivity of the deprived laborer. What is thus fantastic in the notion of the proletariat is that it endows the subject of utmost deprivation with a supreme ideational power of mind ahead of any educational, cognitive, or institutional amplification of such an act. By means of the October revolution, this standpoint is enacted even before Bildung can duly be distributed among the socially deprived, i.e. utterly prematurely. Let us imagine that someone is alleged to be a philosophical subject before s/he has acquired the sufficient productive and institutional means, or simply skills, to confirm this position. Such an act would be conditioned not by condescending overtures to integrate the inferior; but, on the contrary, it would engage an ethics in which it is precisely deprivation that becomes the point of departure for constructing the universal subject of knowledge, thought, and the common good. Such necessity is conditioned by the fact that for Marx only the proletarian consciousness - by the token of its utmost deprivation - can truly mirror the objectivity of being; hence it can de facto represent the most generalized, universal, and socialized mode of mind. We have thus a supreme subject of mind/knowledge and the common good before this subject can provide a proper edification to represent its role. Yet precisely this premature act of empowering and instituting the still immature subject of enlightenment was the paradoxical task of the October revolution. This coercive institution of a political economy of radical deprivatization in Soviet society created

In regard to the revolutionary transformation of the gap between the "intelligentsia” and the working class see Igal Halfin's Language and Revolution. Making Modern Political Identities. London: Frank Cass, 2002. 
a situation in which the relations of production functioned as a common good before technological means or productive forces could adequately correspond to them. It meant that all infrastructures, things, and humans had to perform the social good - including the new politics of knowledge and education - ahead of being sufficiently edified or equipped to perform such an imperative.

$$
* * *
$$

Hence, contrary to the widespread opinion that the failures of the socialist revolution in the USSR were mainly due to insufficient socialism, one could argue that the failure and demise of socialism resulted from an excess of communist features, rather than from their lack.

According to stereotypical interpretations - both from the right and from the left - socialism and its communist components were confined to the jargons of ideology and partocracy, and were only formally communist - imposed upon society from above - while societal infrastructure was not in fact communist or even socialist at all. Antonio Negri suggests that even the sprouts of grassroots proletarian agency that existed in the Soviet Union were eradicated by the disciplinary apparatus (2017a). Moreover, for Negri, planning and party institutions are equal to capitalist accumulation and monopoly on the state's behalf (2017b: 835-849). Consequently, Soviet society is regarded by him as de facto capitalist, and as only formally employing lexicons of the communist ideal.

Étienne Balibar too, in his classic oeuvre, On the Dictatorship of Proletariat, argues that socialism was simply a transition from capitalism to communism, and that there was no such thing as the socialist mode of production (as against the capitalist and communist ones). Socialism is a continuation of class struggle headed by proletariat; it is a democratic transformation of capitalism rather than a new episteme and ontology of sociality and production (Balibar 1977: 140-145). Consequently, not only had Soviet socialism nothing to do with communism, but, it was not even socialism at all, as long as the class struggle was terminated with Stalin's leadership.

These views are important. Yet they ignore the two most important components of historical socialism. Claiming that Soviet socialism dismissed class struggle is to consider struggle within a capitalist logic - as the resistance of the disenfranchised class against the privileged, or as the critique of the capitalist features of the economy that dominate sociality. Yet in historical socialism, class struggle could not have had the same form. Within capitalism, the anti-capitalist struggle tends to undermine the capitalist system, it revolts against the system. The political-economic system is grounded in inequality and is thus unfree; then the main syn- 
drome of liberation is to resist this systemic subjugation. In socialism it is the other way around. It is the political-economic system that is determined by equality, and hence the system itself is even freer than mundane sociality; it is oriented toward the common good much more than 'ordinary life' and its particularities are; hence sociality has to stretch toward the system rather than subvert it. For example, when the system of production and wage remuneration equalized the income of laborers of various skills in socialist countries, separate social groups or individuals were critical of such a tendency, as it neutralized qualification of the work done and blocked any opportunity for surplus incomes for those specific, more skilled social groups. Contrary to the stereotype that socialist society was falsely socialist as it was ruled by the dogmatic imperatives of partocracy, I would argue that the party was simply the organ responsible for the provisions of the common good - yet the communist hypothesis is broader than the party. Thus historically, the party itself rather aspired to become worthy of the communist condition, often avowing its own deviations. The struggle then is not in transgressing, but in correlating the already established communist components within socialism. In that sense, historical socialism was nothing but the perpetual front line of class struggle in every field against the remaining traits of capitalism; so that the struggle turned into a permanent vigilance against any fascination with capitalism and its traits - in cultural politics, economics, and social life. In fact, the civil war never ended in the media, culture, and art of the Soviets. Once many traits of communism have already been established in a society, each citizen and his or her consciousness becomes the site of such a battle. Class struggle evolves into a regime of self-critique and of constant anti-capitalist vigilance.

Balibar's view of historical socialism does not take into account the logical paradox that inheres in the epistemological, ontological, and temporal overturning caused by the October revolution. Even if it is true that socialism was an insufficient communism, it was so not because the communist components were too remote from socialism and were yet to be achieved in its political economy and social infrastructure, but on the contrary; communism remained yet remote because too many communist components had already been established in the political economy, education system, and relations of production ahead of time yet human factors and drawbacks in production had rendered those communist components unimplementable. Hence the inevitability of the socialist modality of transition. The Bolsheviks' resort to NEP is a classic case that exemplifies this point. Thus the temporal paradox inheres not in the fact that socialism is a transitory stage after capitalism, and that it therefore knows little of communism. On the contrary: precisely because the October revolution achieves too many of the conditions of communism ahead of time, and precisely because the political and eco- 
nomic system becomes more communist than life itself, communism inevitably manifests itself in the guise of socialism.

The dictatorship of proletariat is then the inner moral code of any subject. It subsists in the criminalization of any deviation from the principle of the common good and is not in need of the classical perpetual anti-capitalist antagonism between the less and the more privileged, as long as revolution has already criminalized class antagonism and instituted the proletariat's dictatorship as law. So the aporia of the struggle for more communism after a successful revolution is not in further resistance to capital; after the socialist revolution, the dictatorship of the proletariat and class struggle are aimed at preserving and equipping an already achieved condition of social classlessness; which is too difficult to sustain because productive forces and consciousness have not yet fully matured to its level.

To repeat, the logical puzzle with Soviet socialism was that its political-economic systems contained more elements of communism and a bigger dose of socialism than daily existence. If this were not so, the economic infrastructure of Soviet sociality would not have generated so many shadow areas in production, trade, planning, etc. - confirming a hidden human craving and desire for capitalist modes of life. The issue lay not simply in the rigidity and inflexibility of networks of production, but first and foremost in an incapacity to endure the severe experience of a non-surplus economy.

Let's imagine a worker as a proletarian that is announced already in situ, hic et nunc, a universal historical subject of the common good, knowledge, and thought, but it might be that s/he has not yet acquired the productive forces, or even the capacities, that would match this universality. The question lies not at all in dividing the proletariat into those proper and false, nor in dividing the Soviet project into an immaculate system and flawed individuals. Rather, the incompatibility between the system and life is engendered by the almost inhuman provisions of the common good, in case they happen to be fully realized.

We can introduce a quasi-theological comparison to this scenario. Let's imagine that a utopia is, paradoxically, already accomplished before it is duly projected and organized. Let's infer that we get into the paradise abruptly and materially, despite our sins, and before our sins have been atoned, i.e. even before we are prepared ourselves for paradise, and regardless of whether we would like at all to be there. In this case paradise would seem a torture. The Orthodox sermon traditionally posits that hell does not exist. God created neither evil nor hell. They have no ontology. God gave freedom to human beings (including freedom to sin) merely because it was in freedom that a human being's likeness to God could be confirmed. Thus hell has no special location and is not meant as any special punishment for the sinner. Hell is simply the incapacity to sin when 


\section{Keti Chukhrov}

one still desires to sin, when being in paradise makes sinning empirically impossible. Yet it is too difficult to get rid of the desire to sin when one gets into paradise ahead of time, prematurely. Thus the sinner needs and desires to commit certain acts, which are empirically unimplementable in paradise and therefore cause suffering to the "sinner," who is unable to "sin." (For example, in paradise there is no body, and hence no bodily affects and desires; but if we get into paradise, preserving our bodily affects, desires and passions, we will find them empirically unimplementable in paradise, simply by the token of the absence of empirical bodily functions in the paradisical afterlife.) Therefore the struggle to sustain oneself in paradise would consist in fitting into and stretching toward an already attained paradise, it would be in unlearning to commit acts that are unimplementable in paradise, and even in getting rid of such a desire.

Similarly with an already existing socialism or communism: one is already inscribed into communist surroundings, but one cannot endure it, because one's desires (on the imaginary and phantasmatic level) are still with capitalism, with "sin." In this case, sin (capitalism) continues to exist, but only as one's private longing for sin, and despite one's being already in paradise (communism). Consequently, it makes no sense to criticize or to resist "the nightmare of paradise" for the sinner, if it is simply his or her imperfection which makes of that paradise a hell. Critique of one's own sin would not mitigate the suffering; only the cessation of sin, flight from paradise, or sheer cancellation of the regime of paradise could put a stop to the sinner's suffering.

In a situation in which utopia becomes a social and even material fact, when it is an immanent present reality, one is permanently under the threat of not being adequate to the already existing social good. Hence the obsession in Soviet art, literature, culture, and philosophy with adapting to the laws of communist society rather than evading them. The continuation of the revolutionary act would thus consist in stretching toward the social commons, in striving for adequacy with them, rather than in fleeing from a societal structure perceived as power, authority, or apparatuses.

Consequently, it is important to keep in mind the epistemic divergences between capitalist and non-capitalist societies when engaging in self-critique and emancipatory resistance. For example, for Althusser, self-critique and philosophical theory were aimed at sustaining class struggle. Yet in both theory and practice, class struggle could only evolve against the existing ideas of the common good and established social goals, in so far as they were for Althusser the ideological traps of bourgeois sociality and its false humanism. In a post-revolutionary non-capitalist society, conversely, various modes of achieved equality are so much endangered by the restitution of former capitalism and the reemergence 
of a newly fashioned bourgeoisie, that the struggle is not between the existing social groups, but is aimed against the imaginaries of bourgeois life, its potential reemergence and its political economy; i.e. the struggle becomes the defense of the already acquired ethics of noncapitalist relations of production, rather than transgression of the existing rules of social apparatuses.

Thus, the actual involvement of the cognitive class in a progressive politics of the common good would only be possible on the condition that one goes beyond mere solidarity between the middle class ("cognitariat") and the proletariat: the middle class, notwithstanding its cognitive superiority, would have to sacrifice its subjectivity by ceding primacy to the proletariat as the subject of history (of production and knowledge). This was the idea behind Soviet socialism - the idea that the present day cognitariat is unable to realize. This is because, as John Roberts writes in the introduction to his Self-Love and the Love of Capitalism, the link between working class experience and systemic social transformation has become incoherent and discontinuous (Roberts 2019: 11).

\section{Conclusion}

Thus, the radical and premature endowment of the proletariat with social and cognitive hegemony in the Soviet Union evolved as the utmost socialization of former inequalities, guaranteeing social hegemony to the proletariat. Yet interestingly, it is exactly this coercive securing of social equality - which presupposed the decline of struggle in the form it had taken under capitalist conditions of inequality - that was often misunderstood in the Althusserian and post-Althusserian critique of the Soviet Union as the rejection of social struggle and as the pacification of class antagonisms (Althusser 1976).

The October revolution is thus an example of how a political decision about the proletariat's social and cognitive hegemony precedes the infrastructural and technological back-up of emancipatory procedures. This is because there is no independent ontology of techno-intelligences or cybernetic expansions that generate sociality, as was the idea of Gilbert Simondon (Simondon 2016). It is the other way round: the will for new sociality constructs and determines the goals for the overall development of productive forces and technology. 


\section{Keti Chukhrov}

\section{References}

Althusser, Louis (1976). Essays in Self-Criticism. London: NLB.

Berardi, Franco “Bifo” (2017). Futurability. The Age of Impotence of Future Horizons. London: Verso.

Badiou, Alain (2010). Communist Hypothesis. Trans. David Macey, Steve Corcoran. London: Verso.

Balibar, Etienne (1977). On the Dictatorship of Proletariat. Trans. Grahame Lock. London: New Left Books.

Bratton, Benjamin (2016). The Stack. On Software and Sovereignty. Cambridge, MA: MIT Press.

Bryant, Levi (2012). “On Capitalism as Hyperobject.” Larval Subjects. https://larvalsubjects.wordpress.com/2012/08/04/mckenzie-wark-how-do-you-occupy-an-abstraction.

Fraser, Peter (2016). Life After Capitalism. London: Verso.

Groys, Boris (2010). The Communist Postscript. Trans. Tomas Ford. London: Verso.

Halfin, Igal (2000). From Darkness to Light: Class, Consciousness, and Salvation in Revolutionary Russia. Pittsburgh, PA: University of Pittsburgh Press.

Halfin, Igal, ed. (2002). Language and Revolution. Making Modern Political Identities. London: Frank Cass.

Hegel, Georg Wilhelm Friedrich (1977). Phenomenology of Spirit. Trans. Arnold Vincent Miller. Oxford: Oxford University Press.

Lazzarato, Maurizzio, and Eric Alliez (2016). “To Our Enemies.” E-flux. http://www.eflux.com/journal/78/82697/to-our-enemies.

Lazzarato, Maurizzio, and Eric Alliez (2017). Wars and Capital. Los Angeles, CA: Semiotext(e).

Lenin, Vladimir (1960-1970 [1917]). The State and Revolution: the Marxist Theory of the State and the Tasks of the Proletariat in the Revolution. In Collected Works, Volume 25. Moscow: Progress Publishers.

Lukács, Georg (1971 [1923]). History and Class Consciousness. Trans. Rodney Livingstone. Cambridge, MA: The MIT Press.

Magun, Artemy (2008). Negative Revolution. Saint Petersburg: European University Press, 2008.

Negri, Antonio (2014). "Reflections on Accelerazionista Policy of Williams and Srnicek". Break the Code. https://socialecologies.wordpress.com/2014/02/17/antonio-negri-reflections-on-accelerazionista-policy-of-williams-and-srnicek.

Negri, Antonio (2017a). “The Common Before Power: An Example.” E-flux. http:// www.e-flux.com/journal/87/169460/the-common-before-power-an-example.

Negri, Antonio (2017b). “Soviet: Within and beyond the 'Short Century'." South Atlantic Quarterly 116: 4, 835-849.

Platonov, Andrey (1988). “No odna dusha u cheloveka” [But a Man Has One Soul] [1924]. In Gosudartvenny Zitel [State Resident], Moscow: Sovetsky Pisatel.

Read, Jason (2016). The Politics of Transindividuality. Leiden: Brill.

Rifkin, Jeremy (2011). The Third Industrial Revolution. Basingstoke: Palgrave Macmillan. 
Roberts, John (2019). Self-Love and the Love of Capitalism. Manuscript.

Simondon, Gilbert (2016). On the Mode of Existence of Technical Objects. Minneapolis MN: Univocal Publishing.

Srnicek, Nick, and Alex Williams (2014). "Manifesto for an Accelerationist Politics.” In \#Accelerate: The Accelerationist Reader, ed. Robin Mackay and Armen Avanessian, 347-363. Falmouth and Berlin: Urbanomic/MerveVerlag.

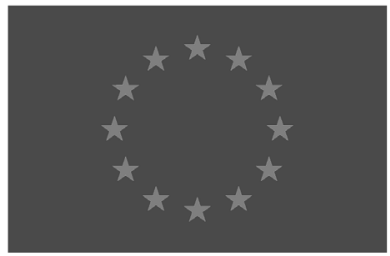

Funded by the European Union 